\title{
Molecular and Morphological Heterogeneity of Neural Precursors in the Mouse Neocortical Proliferative Zones
}

\author{
Jonathan S. Gal, ${ }^{1}$ Yury M. Morozov, ${ }^{2}$ Albert E. Ayoub, ${ }^{2}$ Mitali Chatterjee, ${ }^{1}$ Pasko Rakic,, 3 and Tarik F. Haydar ${ }^{1}$ \\ ${ }^{1}$ Center for Neuroscience Research, Children's Research Institute, Children's National Medical Center, Washington, DC 20010, and 2Department of \\ Neurobiology and ${ }^{3}$ Kavli Institute for Neuroscience, Yale Medical School, New Haven, Connecticut 06510
}

The proliferative ventricular zone (VZ) is the main source of projection neurons for the overlying cerebral neocortex. The number and diversity of neocortical neurons is determined, in part, by factors controlling the proliferation and specification of VZ cells during embryonic development. We used a variety of methods, including in utero electroporation with specific cellular markers, computerassisted serial EM cell reconstruction, and time-lapse multiphoton imaging to characterize the molecular and morphological characteristics of the VZ constituents and to capture their behavior during cell division. Our analyses reveal at least two types of dividing cells in the VZ: (1) radial glial cells (RGCs) that span the entire neocortical wall and maintain contact both at the ventricular and pial surfaces throughout mitotic division, and (2) short neural precursors (SNPs) that possess a ventricular endfoot and a basal process of variable length that is retracted during mitotic division. These two precursor cell classes are present concomitantly in the VZ, but their relative number changes over the course of cortical neurogenesis. Moreover, the SNPs are morphologically, ultrastructurally and molecularly distinct from dividing RGCs. For example, SNPs are marked by their preferential expression of the tubulin $\alpha$-1 promoter whereas RGCs instead express the glutamate-aspartate transporter and brain lipid binding protein promoters. In contrast to recent studies that suggest that RGCs are the sole type of VZ precursor, the present study indicates that the VZ in murine dorsal telencephalon is similar to that in human and nonhuman primates, because it contains multiple types of neuronal precursors.

Key words: neocortex; stem cell; progenitor; organotypic; multiphoton; radial glial cell

\section{Introduction}

It is well established that neocortical neural precursor cells produce a wide array of neurons and glial cells during embryonic development (McConnell, 1988; Rakic, 1988). However, little is known about the cellular and molecular determinants generating this diversity. Numerous studies have suggested that the ventricular zone (VZ) stem cells generate committed neuronal, glial, and bipotential progenitors, each restricted to the production of one or more types of postmitotic cells (Maric et al., 2000; McCarthy et al., 2001; Piper et al., 2001; Cai et al., 2002b; Liu et al., 2002; Shen et al., 2002; Maric et al., 2003; Aguirre and Gallo, 2004). Indeed, multipotent radial glial cells (RGCs) and distinct committed neuronal and glial progenitors have been identified in the human and monkey VZ (Levitt et al., 1981, 1983; Ostenfeld and Svendsen, 2004; Zecevic, 2004). In contrast, recent reports suggest that the rodent neocortical VZ is composed primarily of multipotential RGCs, which generate all of the dorsally derived neocortical cells (Noctor et al., 2002; Fishell and Kriegstein, 2003; Weissman et al.,

Received June 20, 2005; revised Dec. 8, 2005; accepted Dec. 8, 2005.

This work was supported by National Institutes of Health-National Institute of Neurological Disorders and Stroke Grant NS051852 and the Children's National Medical Center Board of Visitors (T.F.H.) and by grants from the United States Public Health Service (P.R.). We acknowledge the technical assistance of Klara Szigeti, Tyler Bysshe, and Melissa Shaya, as well as critical comments on this manuscript by Vittorio Gallo and Bruce Krueger.

Correspondence should be addressed to Dr. TarikF. Haydar, Center V-Neuroscience, Children's Research Institute, Children's National Medical Center, George Washington University School of Medicine, Suite 5346, 111 Michigan Avenue Northwest, Washington, DC 20010. E-mail: thaydar@cnmcresearch.org.

DOI:10.1523/JNEUROSCI.4499-05.2006

Copyright $\odot 2006$ Society for Neuroscience $\quad$ 0270-6474/06/261045-12\$15.00/0
2003) including cortical astrocytes (Pixley and de Vellis, 1984; Misson et al., 1988; Takahashi et al., 1990; Hunter and Hatten, 1995; Kamei et al., 1998; deAzevedo et al., 2003).

The basic mechanisms of neocortical development are remarkably similar across mammalian species. For example, neocortical formation proceeds via a conserved sequence: (1) rapid founder cell expansion, (2) a period of neurogenesis from $\mathrm{VZ}$ and subventricular zone (SVZ) precursors, and (3) a depletion of the VZ cells as neurogenesis subsides. During this sequence, bipolar VZ precursors exhibit interkinetic nuclear migration (INM), where the cell nucleus moves in concert with the cell cycle and descends to the ventricular surface just before entering metaphase (Sauer and Walker, 1959; Angevine and Sidman, 1961; Caviness and Sidman, 1973; Rakic, 1974; Shoukimas and Hinds, 1978; Nowakowski and Rakic, 1981; Caviness, 1982; Rakic, 1995). This INM, considered a hallmark of VZ cells, has been used to highlight and analyze neocortical precursor cells.

Initially, light and electron micrograph studies demonstrated completely rounded mitotic forebrain progenitors at the ventricular surface (Sauer, 1935; Stensaas and Stensaas, 1968; Hinds and Ruffett, 1971) that were morphologically distinct from RGCs, which span the full thickness of the neocortical wall, even during mitosis (Kamei et al., 1998; Miyata et al., 2001; Noctor et al., 2001; Noctor et al., 2002; Zecevic, 2004). Maintenance of the RGC pial connection is important because immature neurons migrate to the overlying cortical plate using the RGC ascending fibers as a substrate (Rakic, 1971, 1972; Sidman and Rakic, 1973; Hatten, 
1993; Nadarajah et al., 2003). Several groups have demonstrated recently that rodent RGCs directly generate cortical neurons and have concluded that most, if not all, VZ cells are RGCs (Miyata et al., 2001; Noctor et al., 2001; Malatesta et al., 2003; Anthony et al., 2004; Noctor et al., 2004). However, the proposition that RGCs are the preponderant $\mathrm{VZ}$ cell type stands in contrast to the previous identification of shorter neuronal progenitors. These discrepancies justify re-examination of the cytological composition of the proliferative VZ by combining both modern and classical methods.

\section{Materials and Methods}

This study used a variety of strategies, including organotypic slice preparations, in utero transfection of fluorescent reporter genes, lipophilic dyes, and time-lapse multiphoton and electron microscopic reconstructions to fully label VZ cells. These diverse and complimentary methods were used to characterize VZ cells from the ultrastructural level to the dynamic physiology of living cells as they progressed through mitosis. Most importantly, this multipronged approach avoided the possible sampling bias inherent to each of the individual methods when used alone.

In utero transfection and plasmid vectors. Electroporation was used to transfect VZ cells in utero with mammalian expression vectors as described previously (Akamatsu et al., 1999; Miyasaka et al., 1999; FukuchiShimogori and Grove, 2001; Tabata and Nakajima, 2001). All animal procedures conformed to United States Department of Agriculture regulations and were approved by the Children's National Medical Center and Yale Institutional Animal Care and Use Committees. Briefly, uterine horns of timed-pregnant dams were exposed by midline laparotomy after anesthetization with ketamine and xylazine. One microliter of plasmid DNA $(3-4 \mu \mathrm{g} / \mu \mathrm{l})$ mixed with $0.03 \%$ fast green dye in phosphate buffer was injected intracerebrally using a pulled micropipette through the uterine muscle and amniotic sac. The anode of a Tweezertrode (Genetronics, San Diego, CA) covered in SignaGel (Parker Laboratories, Fairfield, NJ), was placed outside of the uterine muscle over the dorsal telencephalon of the embryo. Five $33 \mathrm{~V}$ pulses (50 ms duration; each separated by $950 \mathrm{~ms}$ ) were applied using a BTX ECM830 pulse generator (Genetronics). After electroporation of all embryos in one uterine horn, the uterus was replaced within the abdomen, the cavity was filled with warm sterile physiological saline, and the abdominal muscle and skin incisions were closed with silk sutures. After intraperitoneal injection of yohimbine $(0.2 \mu \mathrm{g} / \mathrm{gm}$ bodyweight $)$ for xylazine reversal, animals were left to recover in a clean cage (animals usually recovered within $10 \mathrm{~min}$ ). Very little embryo mortality was found after electroporation (4\% of total embryos) and no dams died from the surgery. These electroporation conditions yielded very high transfection efficiency; transfected cells were confined to the VZ and were not initially present in the SVZ, intermediate zone (IZ), or cortical plate (CP).

We used several different plasmid vectors for transfection. General labeling to elucidate cell morphology was performed with a plasmid expressing free cytoplasmic EYFP (pEYFP-C2) and a plasmid expressing farnesylated enhanced green fluorescent protein (pEGFP-F) (Clontech, Palo Alto, CA). E/nestin:P/hsp68:EGFP (gift from S. Goldman, University of Rochester, Rochester, NY) labeled nestin-expressing precursor cells, expression of pactin-YFP (Clontech) yielded an actin-YFP fusion protein, which elucidated the cytoskeleton of $\mathrm{VZ}$ cells, and the $\mathrm{pT} \alpha 1$ : hGFP plasmid (gift from S. Goldman) expressed humanized GFP under the control of the T $\alpha 1$ promoter in a selected group of VZ progenitors. For promoter-based assays, promoters for glutamate-aspartate transporter (GLAST) (gift from D. J. Volsky, Columbia University, New York, $\mathrm{NY}$ ), brain lipid binding protein (BLBP), and T $\alpha$-1 were subcloned into EGFP or a Discosoma sp. red fluorescent protein variant (DsRed2) promoterless plasmids (pEGFP-1 and pDsRed2-1; Clontech). All cell counting was performed on coded samples so that the experimenter was blind to the condition. For cotransfection experiments, EGFP- and DsRed2based plasmids were mixed at a 50:50 ratio.

Slice cultures. Organotypic slices were prepared $24-48 \mathrm{~h}$ after electroporation from embryonic brains as described previously (Haydar et al.,
1999; Haydar et al., 2000; Haydar et al., 2003). Briefly, $300 \mu \mathrm{m}$ coronal slices were obtained in ice-cold MEM using a McIlwain tissue chopper (Mickle Laboratory Engineering, Gromshall, UK) and transferred into serum-free medium (SFM; neurobasal medium supplemented with B27, N2, and glutamax; Life Technologies, Gaithersburg, MD). After $4 \mathrm{~h}$ of recovery, slices were embedded in growth factor-reduced Matrigel on a $15 \mathrm{~mm}$ coverslip fixed onto a heated open superfusion chamber (RC25F; Warner Instruments, Hamden, CT). Preheated SFM was pumped over the slices for the length of the imaging experiment (usually $8-24 \mathrm{~h}$ in duration) and the slice temperature was maintained at $37^{\circ} \mathrm{C}$. We used an infrared pulse laser for two-photon excitation 100-150 $\mu \mathrm{m}$ below the surface of the tissue to image undamaged portions of the slice.

Multiphoton microscopy and image analysis. All multiphoton imaging was performed on a Zeiss (Jena, Germany) LSM 510 Meta NLO system equipped with an Axiovert 200M microscope (Zeiss) direct-coupled to a Mira 900F laser pumped by an $8 \mathrm{~W}$ Verdi laser (Coherent Laser Group, Santa Clara, CA). EGFP was excited at $850 \mathrm{~nm}$ and YFP was excited at 890 $\mathrm{nm}$. Time-series experiments were conducted under oil immersion, either with $25 \times$ or $40 \times$ objectives, and consisted of 15 - to $40-\mu$ m-thick z-stacks collected every 6 min. Typical laser throughput was $10-20 \%$, which corresponded to $20-40 \mathrm{~mW}$ at the sample. Time-series experiments were analyzed with LSM 510 software. For the presentation of movies, each z-stack was projected onto one optical slice per time period, and the resulting frames were assembled and compressed using Adobe Premiere (Adobe, San Jose, CA).

Confocal microscopy, DiI labeling, and cell counting. Frozen sections of $40 \mu \mathrm{m}$ thickness were acquired from pEGFP-C2- and pEGFP-Felectroporated brains, which had been fixed in $4 \%$ paraformaldehyde (PFA) overnight and equilibrated in $30 \%$ sucrose in $1 \times$ PBS. Sections with transfected VZ cells were stained with propidium iodide to counterstain DNA. Three-dimensional reconstructions of VZ cells were prepared using the LSM 510 imaging program and three-dimensional (3D) module, by either projecting stacks around the $y$-axis and/or by surface rendering. Z-stacks $25-40 \mu \mathrm{m}$ thick, composed of 1024 by 1024 pixel, 1 - $\mu$ m-thick optical sections, were collected using a $40 \times$ oil-immersion lens. For EGFP-C2 studies to count the ratio of ascending fibers and transfected soma (see Fig. 2), two images were obtained per sample. First, to highlight and enhance all basal cell processes, a high-gain z-stack was taken of the superficial neocortical wall from the SVZ to the pia; all ascending fibers that clearly emanated from VZ cells in the stack and were observable from the VZ to the CP were counted. Subsequently, the numbers of $\mathrm{EGFP}^{+}$cells in the underlying VZ were counted in a second $\mathrm{Z}$-stack taken at lower gain but with identical size and mediolateral position of the first $\mathrm{z}$-stack. For EGFP-F studies to reconstruct mitotic VZ cells, cells in metaphase-to-anaphase were identified based on chromatin organization (containing a mitotic plate or cleavage plane) and were scored as either long or short cells, depending on whether they possessed or lacked basal ascending fibers.

For 1,1'-dioctadecyl-3,3,3',3'-tetramethylindocarbocyanine percholate (DiI) labeling, drops of $1 \mathrm{mg} / \mathrm{ml}$ DiI dissolved in DMSO were placed on a plastic weigh boat and allowed to dry as a lawn of small crystals. The dorsal surface of embryonic brains fixed in $4 \%$ PFA was then rolled onto the crystals to label the pial surface. After 6 weeks of continued immersion in 4\% PFA at room temperature to allow for dye diffusion, brains were embedded in $1 \%$ low-melting-point agarose and sectioned into $50 \mu \mathrm{m}$ slices with a vibratome. Some vibraslices were then counterstained with propidium iodide and imaged using a $543 \mathrm{~nm} \mathrm{HeNe}$ laser. $\lambda$-Stack images were collected using the Meta detector, and DiI and propidium iodide emissions were discriminated post hoc using "spectral unmixing" algorithms established with the analysis of slices stained with DiI or propidium iodide alone. VZ cells in metaphase-to-anaphase were scored as long or short cells if they were or were not DiI-labeled, respectively.

DiI-labeled cells in other vibraslices were photoconverted using 1 $\mathrm{mg} / \mathrm{ml} \mathrm{DAB}$ in $1 \times \mathrm{PBS}$ under illumination by a $100 \mathrm{~W}$ mercury arc lamp through rhodamine filters for $25 \mathrm{~min}$, or until photoconversion was complete. Photoconverted slices were then postfixed with osmium tetroxide, dehydrated, embedded in Durcupan, cut into ultra-thin sections, stained, and imaged in an electron microscope as described in detail 
below. For correlative light/electron microscopic analysis, selected DABcontaining cells before ultra-thin sectioning were also photographed with an Axioplan 2 conventional light microscope (Zeiss).

Electron microscopy and 3 D reconstruction. Embryonic day 13.5 (E13.5) and E16.5 mouse brains ( $n=3$ of each age) were removed from the calvarium and immersed within a fixative containing $4 \%$ paraformaldehyde, $0.2 \%$ picric acid, and $2 \%$ glutaraldehyde in $0.1 \mathrm{~m}$ phosphate buffer overnight at $+4^{\circ} \mathrm{C}$. They were then embedded in $3 \%$ agarose and sectioned at $100 \mu \mathrm{m}$ in the coronal plane on a vibratome. The sections were postfixed with $1 \% \mathrm{OsO}_{4}$, dehydrated, and embedded in Durcupan (Fluka, Buchs, Switzerland) on microscope slides and coverslipped. Selected areas were re-embedded into Durcupan blocks and cut by a Reichert ultramicrotome into 70-nm-thick sections. Long series of sections (up to 200) were collected using Domino rack (Rowley and Moran, 1975). These sections were then stained with uranil acetate and lead citrate and imaged in a JEM 1010 (JEOL, Akishima, Japan) electron microscope equipped with a Multiscan 792 digital camera (Gatan, Pleasanton, CA). Images of arbitrarily selected cells from every single serial section were made at $10,000 \times$ magnification. 3D reconstructions were performed using the Reconstruct software package (Fiala and Harris, 2001), publicly available at http://synapses.bu.edu/.

For EGFP-F/DAB studies, E13.5 mouse brains were electroporated in utero (see above). Twenty-four hours later, brains were removed from the skull and fixed in 4\% PFA and $0.5 \%$ glutaraldehyde in $0.1 \mathrm{M}$ phosphate buffer overnight at $4^{\circ} \mathrm{C}$. Vibratome sections were prepared as above. The sections were immersed in $30 \%$ sucrose solution in phosphate buffer during $2 \mathrm{~h}$, freeze-thawed over liquid nitrogen and, after extensive washes, blocked in $5 \%$ bovine albumin. The sections were incubated for $48 \mathrm{~h}$ at $4^{\circ} \mathrm{C}$ in rabbit anti-GFP polyclonal antisera (Invitrogen, Leiden, The Netherlands; dilution 1:2000). Sections were extensively washed in buffer and immersed in solutions of biotinylated goat anti-rabbit IgGs (1:300) and developed by the Elite ABC kit (both from Vector Laboratories, Burlingame, CA) following manufacturer instructions with $3,3^{\prime}$ diaminobenzidine- $4 \mathrm{HCl}$ as a chromogen. Control sections were processed omitting primary antibodies or by replacing them with normal rabbit sera (1:100). No specific staining was observed in these sections. The sections were postfixed, embedded, cut into long series of sections, stained, and evaluated in an electron microscope for $3 \mathrm{D}$ reconstructions as described in detail above.

BrdU and Ki67 counterstaining. Embryos were electroporated with pEGFP-F, pT $\alpha 1$ :hGFP, or pEYFP-C2 at time 0 on E14.5. Twenty-four hours later, BrdU was injected intraperitoneally into the pregnant dams at $50 \mathrm{mg} / \mathrm{kg}$ bodyweight every $2 \mathrm{~h}$ for a total of 4 or $6 \mathrm{~h}$ of cumulative labeling. In separate experiments, embryos were collected and fixed for Ki67 immunohistochemistry at $24 \mathrm{~h}$ post electroporation. BrdU immunofluorescence was performed as described previously (Haydar et al., 1999). Ki67 staining was performed with the rabbit anti-Ki67 primary antibody (Novo Castra, Newcastle upon Tyne, UK) at 1:250 dilution followed by a goat anti-rabbit RITC secondary antibody (Jackson ImmunoResearch, West Grove, PA) at 1:200. Short VZ cells and T $\alpha 1$ expressing cells were counted only if they were fully contained within z-stacks.

\section{Results}

We conducted an analysis of the neocortical VZ using a variety of methods to determine the morphology and the expression patterns of VZ cells, and to follow cells using time-lapse imaging as they progressed through mitosis. We observed that the VZ contains two molecularly different precursor cell types that transit through mitosis with markedly different morphology.

Labeling neocortical progenitors via in utero electroporation We used an in situ transfection technique to assay the morphology and cell division dynamics of neocortical VZ precursors. As reported previously, in utero electroporation is a rapid and robust method for labeling cells in situ with mammalian expression vectors (Akamatsu et al., 1999; Miyasaka et al., 1999; Fukuchi-
Shimogori and Grove, 2001; Saito and Nakatsuji, 2001; Tabata and Nakajima, 2001; Hatanaka and Murakami, 2002). One major advantage of electroporation is high transfection efficiency. In addition, because the plasmid is drawn into the $\mathrm{VZ}$ cell somata, electroporation offers the ability to bypass the ventricular surface and the potential to equally sample the VZ population.

We first designed a pulse protocol that restricted transfection to VZ precursors (supplemental Fig. 1, supplemental movie 1, available at www.jneurosci.org as supplemental material). To generate large fields of transfected VZ cells, a plasmid concentration of 3-4 $\mu \mathrm{g} / \mu \mathrm{l}$ was used, with one microliter of this solution injected into the lateral ventricle of fetuses aged E12.5 to E16.5. The hemisphere that received the plasmid was then preferentially electroporated by placing the anode on the outside of the uterine musculature above the injection site, and voltage pulses were then applied. Typically, six to eight fetuses per litter were electroporated, and their position on each uterine horn was recorded relative to the cervix. All of the 20 min survival surgeries proceeded without maternal mortality, and $96.5 \%$ of all fetuses $(n=$ 1015) survived electroporation. The rate of successful electroporation was $76 \%$. Usually, a large swath of the ipsilateral neocortical wall was transfected and only one hemisphere contained transfected cells. Within the transfected swath, transfection efficiency could be as high as $100 \%$, depending on the concentration of plasmid DNA and age of the animal. Cells in electroporated brains began expressing cytomegalovirus (CMV)-driven EGFP as early as $12 \mathrm{~h}$ post surgery (data not shown).

We first characterized the morphology of VZ cells using plasmids encoding EGFP and EYFP under the control of several different promoters on embryonic days spanning the epoch of neocortical neurogenesis (E12.5-E16.5). Care was taken to ensure that all examined cells were fully contained within each tissue section and confocal $\mathrm{z}$-stack. Labeled VZ cells typically fell into two major morphological groups: (1) long bipolar RGCs with a cell body in the $\mathrm{VZ}$ and with endfeet both at the ventricular and the pial surfaces, and (2) cell bodies contained in the VZ anchored by ventricular endfeet that appeared to lack basal ascending processes passing through the superficial neocortical wall. Electroporation using the E/nestin:P/hsp68:EGFP plasmid (Roy et al., 2000) yielded many clear RGCs (which we also refer to as long VZ cells) as well as cell bodies in the VZ that lacked discernable pial projecting processes (Fig. $1 A$ ). We also noted many examples of dividing VZ cells rounded at the ventricular surface that lacked ascending processes, even after transfection with the pactin-YFP vector encoding an actin-YFP fusion protein, which labeled the cytoskeleton (Fig. $1 B$; supplemental movie 2, available at www.jneurosci.org as supplemental material). We have termed these latter type short neural precursor cells. The SNPs were often found immediately next to RGCs. However, in contrast to these mitotic SNPs, RGCs in metaphase were distinguished by clear labeling of the ascending basal process, which was sometimes punctate in appearance when free cytoplasmic fluorescent probes were used (Fig. 1C). In fully reconstructed cells present in areas of low transfection using pEYFP, two types of short interphase VZ cells were found. Some cells had short ascending processes that remained within the VZ, the tips of which were simple and unramified (Fig. 1D). In contrast, other interphase cells possessed filopodia and growth cone-like structures at the tips of their ascending processes (Fig. 1E). The growth-cone-tipped processes are likely to identify newly generated RGCs, which must then re-establish their pial contact, as shown previously (Miyata et al., 2001).

This series of experiments strongly suggested that both short 
and long VZ cells are present simultaneously at all prenatal ages examined. In addition, whereas RGCs divided, maintaining the actin cytoskeleton within their ascending process (supplemental movie 3, available at www.jneurosci.org as supplemental material), SNPs appeared to either retract their process or the actin contained therein during metaphase. Thus, during embryonic neocortical development, dividing RGCs may be joined by a markedly different cell type in the VZ that divides in a manner that would preclude its use as a migrational substrate. To conclusively demonstrate a diversified VZ population, we conducted three separate experiments using light microscopy to quantify the cell types in the neocortical VZ.

\section{Quantification of VZ cell types}

Because long and short VZ cells are principally distinguished by the presence or absence of a pial-contacting process during mitosis, we used DiI staining of the pial surface to retrogradely label VZ cells in fixed E13.5 and E14.5 brains, and then counter stained all nuclei with propidium iodide (PI). After 3D confocal imaging and reconstruction, all cells in metaphase and anaphase at the ventricular surface were scored as either DiI-labeled or unlabeled. DiI-labeled mitotic cells were considered RGCs, whereas unlabeled mitotic cells were scored as SNPs. Six weeks after DiI labeling of the pia (Fig. $2 A-C$ ), $61 \pm$ $8.34 \%$ of mitotic VZ cells were DiI unlabeled, whereas $39 \pm 10.22 \%$ of dividing VZ cells were DiI labeled ( $n=124$ cells; mean \pm SEM) in E13.5 brains. Similarly, there were more DiI-unlabeled cells $(68 \%$; SEM \pm 4.89$)$ than labeled cells (32\%; SEM \pm 11.03$)$ at E14.5 ( $n=157$ cells) (Fig. $2 C)$. The DiI assay therefore indicated that the VZ contains more SNPs than RGCs during corticogenesis. However, in this experiment, newly generated RGCs that had not yet re-established contact with the pial surface would be DiI-unlabeled and would have been counted as short cells. In addition, although it appeared that the pial surface and superficial neocortical wall were saturated with dye in these experiments, it is possible that our labeling technique did not label all of the pial foot processes made by RGCs. Therefore, the RGCs may have been under-sampled in these DiI studies.

To more precisely separate the SNPs from immature RGCs, we compared the number of ascending fibers to the number of VZ cell bodies in fixed samples. Forty-micrometer-thick z-stacks of 1 - $\mu$ m-thick optical sections were collected from brains transfected with pEYFP. Brains containing high transfection efficiency in the neocortical VZ were chosen for this experi-

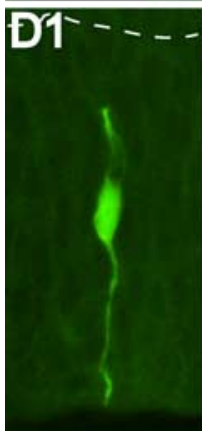

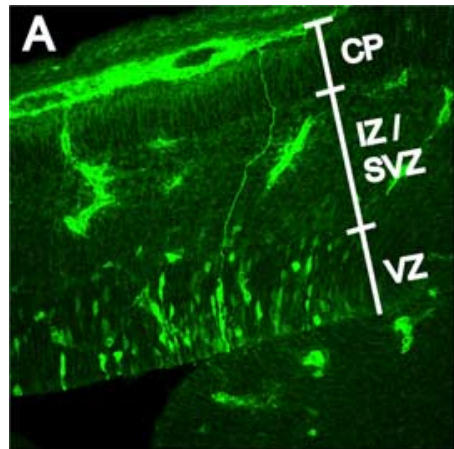
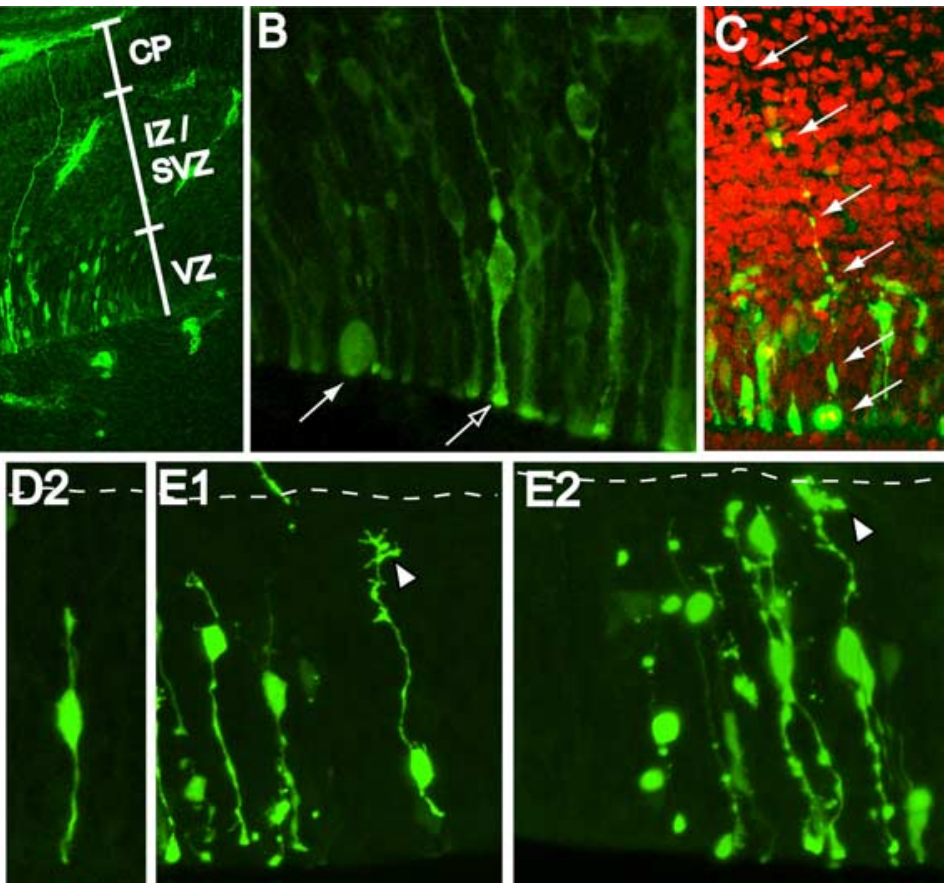

Figure 1. Transfected VZ cells displayed variable morphologies. $\boldsymbol{A}$, Transfection of E/nestin:P/hsp68:EGFP elucidated nestinexpressing VZ cells. Many long RGCs were evident in the midst of shorter VZ cells (SNPs), which lacked long ascending fibers. $\boldsymbol{B}$, Transfection using a plasmid expressing an actin-EYFP fusion protein (pactin-EYFP) also labeled SNPs (filled arrow) and RGCs (open arrow) in the VZ. The SNP in this image is mitotic and rounded at the ventricular surface and lacks an ascending process containing the fusion protein. For 3D reconstruction of this Z-stack, see supplemental movie 2 (available at www.jneurosci.org as supplemental material). C, Dividing RGCs were also evident after electroporation with pEYFP. This section was counterstained with PI (red) to label all cell nuclei. The RGC in this collapsed stack is in anaphase and has a clearly identifiable ascending process (arrows). D1, D2, SNPs are bipolar during interphase periods and possess unramified short ascending processes, which are often contained within the depth of the VZ.E1, E2, Other short VZ cells possessed ascending processes with filopodia or growth cone-like tips (arrowheads). The basal process of the cell in $\boldsymbol{E} 1$ did contact the ventricular surface, but appears displaced in the collapsed stack because of undulation of the ventricular surface. The short VZ cells with growth cone tips are likely long RGCs regrowing the basal process to the pial surface. Collapsed stacks in D1-E2 fully contained all processes of the imaged VZ cells. The dashed lines indicate the superficial boundary of the VZ.
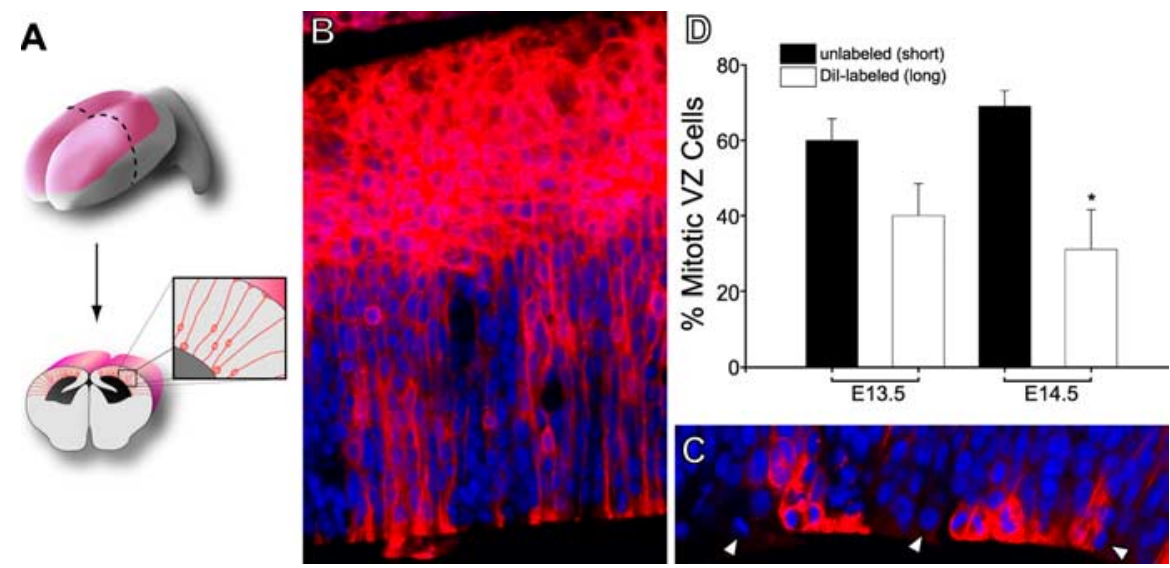

Figure 2. Quantification of VZ cell types: retrograde Dil labeling. $\boldsymbol{A}$, The pial surface of the telencephalic hemispheres were coated with Dil crystals. B, C, Six weeks later, many cells in the CP and IZ were labeled with Dil (red), and mitotic cells (ranging from metaphase to anaphase) at the ventricular surface were scored as Dil-labeled or -unlabeled (C, arrowheads). PI was used to counterstain the cell nuclei (blue). D, More short (Dil-unlabeled) than long (Dil-labeled) VZ cells were found at E13.5 ( $n=124$ total cells) and E14.5 ( $n=157$ total cells). ${ }^{*} p<0.05, t$ test. Error bars indicate SE.

ment (Fig. 3A). Soma contained within the VZ were counted and compared with the number of YFP-labeled ascending fibers in the deep IZ (Fig. $3 B, C$ ). Because cell bodies expressing EYFP were much brighter than the cell processes, each radial section of 

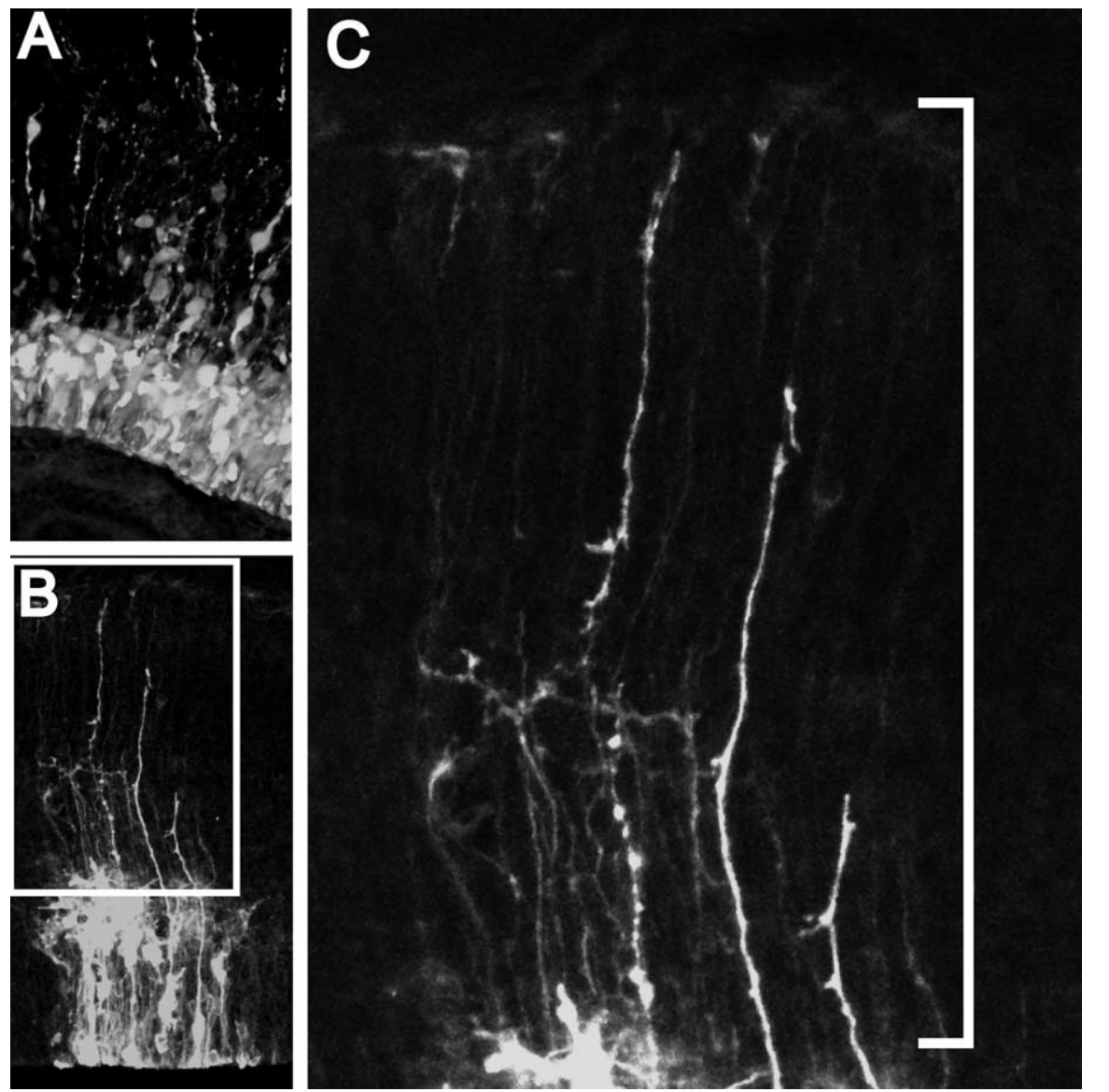

cells. For these reasons, the ascending fiber experiment may have under-sampled the RGCs.

To determine the time-dependent dynamics of even the thinnest cell processes in $\mathrm{VZ}$ cells, we took advantage of the interkinetic VZ cell behavior and assayed VZ cells at mitosis. Although SNPs do extend basal processes during interphase, timelapse imaging experiments show that these fibers are retracted into the cell body as the cells move to the ventricular surface and enter metaphase (supplemental movie 4, available at www.jneurosci.org as supplemental material). Thus, we reasoned that the best time window during which to clearly distinguish SNPs from RGCs is during metaphase and anaphase. In addition, to ensure that all cell processes were fully labeled, regardless of their diameter, we transfected VZ cells with an EGFP-F construct where the farnesylated EGFP product is tagged to the cell membrane. High resolution z-stacks were acquired using 1- $\mu \mathrm{m}$-thick optical sections, and mitotic cells in metaphase and anaphase were scored for the presence or absence of a basal ascending fiber. Optical sections of EGFP-F-transfected cells demonstrated that the EGFP labeling was indeed confined to the plasma membrane. In this stringent analysis, cells with any detectable basal process were counted as RGCs. Twenty-four hours after pEGFP-F electroporation, EGFP-F-labeled cell bodies were found in the VZ and SVZ, and ascending radial fibers were clearly evident coursing through the IZ and CP and terminating at

Figure 3. Quantification of VZ cell types: counting ascending fibers. $A$, In this surface-rendered Z-stack from an $E$ (3.5 fixed $24 \mathrm{~h}$ after electroporation, the density of VZ cells can be compared with the number of ascending radial fibers. $\boldsymbol{B}$, This collapsed Z-stack illustrates the VZ cell/ascending process ratio. The boxed area is shown at higher magnification in $\mathbf{C}$, where ascending radial fibers are clearly evident emanating into the $I Z$. The white line demarcates the counting region where ascending processes were scored.

Table 1. Quantification of VZ cell types: ascending fiber experiment

\begin{tabular}{llll}
\hline & \multicolumn{3}{l}{ Mean percentage \pm SEM } \\
\cline { 2 - 4 } & E14.5 & \multicolumn{1}{l}{ E15.5 } & E16.5 \\
\hline Short & $81.1 \pm 0.41$ & $92.8 \pm 1.22$ & $71.5 \pm 3.71$ \\
Long & $18.9 \pm 0.38$ & $7.2 \pm 1.35$ & $29.5 \pm 3.14$ \\
\hline
\end{tabular}

the neocortical wall was scanned both at low and at high detector gain. The high-gain images (Fig. 3C) enhanced the dim elements and were used to count all observable ascending processes emanating from the VZ. At all ages examined, we counted more cell bodies in the VZ than radial fibers ascending through the neocortical wall (Table 1). This experiment, using in situ labeling methods to discriminate whether VZ cells possessed ascending fibers into the SVZ and IZ, again suggested that there were many SNPs in the neocortical VZ. However, RGC fibers are known to fasciculate as they ascend through the neocortical wall (Rakic, 1972; Gadisseux et al., 1989; Takahashi et al., 1990), and so the brighter processes counted may have been fascicles of multiple radial fibers not resolvable by light microscopy. In addition, RGC fibers have been observed to thin considerably during mitosis (Noctor et al., 2001; Miyata et al., 2002). Thus, the free cytoplasmic EYFP expressed by transfected cells may have been largely excluded and/or withdrawn from thin fibers of the mitotically active long the pial surface (Fig. $4 A$ ). In contrast to the bipolar appearance of VZ cells, SVZ cells appeared multipolar, as described previously (Tabata and Nakajima, 2003; Noctor et al., 2004). After 3D reconstruction, short dividing cells completely lacking basal processes were found at the VZ surface (Fig. $4 \mathrm{~B}$ ), sometimes in close proximity to long dividing cells (Fig. $4 C$ ). Counts of VZ cells in metaphase-anaphase on each day from E13.5 to E16.5 are presented in Figure $4 D$ and Table 2. The ratio of SNPs to RGCs was $\sim 50: 50$ at all ages examined, except for E14.5 when there were significantly more SNPs by $t$ test $(p<0.05)$. Thus, all of our attempts to quantify cell types in the prenatal neocortical VZ detected a significant number of short mitotic neural precursors, which progress through mitosis quite differently than long RGCs. When membrane labeling and the distinct mitotic behavior of long and short cells are simultaneously assayed throughout neocortical neurogenesis, we find that there are roughly equal numbers of RGCs and SNPs in the VZ.

\section{Electron microscopic determination of VZ cell morphology}

We performed a serial section EM analysis of the E13.5 and E14.5 $\mathrm{VZ}$ to determine the ultrastructural characteristics of VZ precursors and to convincingly determine the length of dividing cells in the VZ. Examination of random EM sections indicated that the majority of cell body profiles with the ultrastructural features of mitotic cells (e.g., chromosomes and centrioles in the cytoplasm, 
or two dark postmitotic nuclei) were round or ovoid and lacked the initial segments of radial processes. However, the prevalence of these rounded profiles may be attributable to the fact that the radial processes were very thin $(\sim 1 \mu \mathrm{m}$ diameter) and therefore may have been outside the plane of the section. To obtain more conclusive data, we obtained complete 3D reconstructions of dividing cells from gapless, contiguous series of ultra thin $(70 \mathrm{~nm}$ thick) sections. Both short (Fig. 5A) and long cells (supplementary Fig. 2, available at www.jneurosci.org as supplemental material) were traced and reconstructed in unlabeled tissue. Although the cell profiles in each section of these reconstructions were unambiguous because of excellent fixation, it was difficult to prove the absence of the finest curved processes because of the following inherent methodological limitations: (1) cell bodies and processes are densely packed in the $\mathrm{VZ}$ and have similar cytoplasmic density, and (2) the cell membrane cannot always be definitively traced when processes are cut tangentially. To overcome these technical limitations, we performed reconstructions of DAB-stained tissue after in utero EGFP-F electroporation of VZ cells. The accumulation of electron-dense DAB precipitation inside transfected cells and its absence in adjacent, nontransfected cells greatly improved the signal-to-noise ratio by clearly demarcating the boundaries between cells and assured that all extrusions of the cell membrane were traced and reconstructed (Fig. 5B).

In total, four mitotic SNP cells (two from unlabeled tissue and two EGFP-F/DAB-stained tissue) completely lacking ascending processes were fully reconstructed (Fig. 5). Two other mitotic RGCs (one from unlabeled and one from EGFP-F/ DAB tissue) demonstrated a well established radial process emanating from the basal pole of the cell body. One of these reconstructed RGCs extended a process that terminated with a growth cone $50 \mu \mathrm{m}$ from the ventricular surface (supplemental Fig. 2, available at www.jneurosci.org as supplemental material). Another dividing RGC could not be traced completely because its process was truncated at the surface of the section as it coursed away from the VZ (data not shown), but it was of sufficient length to classify it as a long cell.

To resolve the full span of the ascending processes from VZ to the pial surface, we analyzed mitotic cells retrogradely labeled with DiI placed on the pia and photoconverted in DAB with correlative light/electron microscopy. After initial light micrographs of the labeled cells were acquired (Fig. 6A), the cells were serially sectioned and imaged via EM (Fig. 6B). Three cells were arbitrarily selected for analysis because they demonstrated cell bodies rounded at the ventricular surface and were not masked by other stained cells. Using the ultrastructural criteria of condensed chromatin and centriole pairs, all of these three cells were mitotic: one was in metaphase (Fig. 6) and two were in prometaphase (data not shown). In addi-
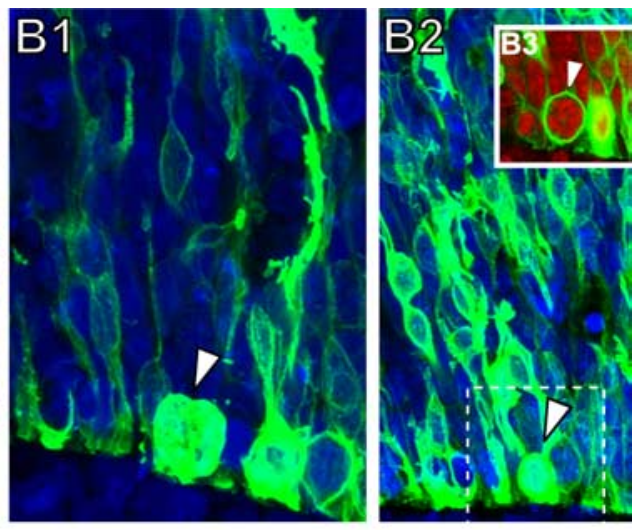

24 hr EGFP-F Electroporation

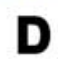

D

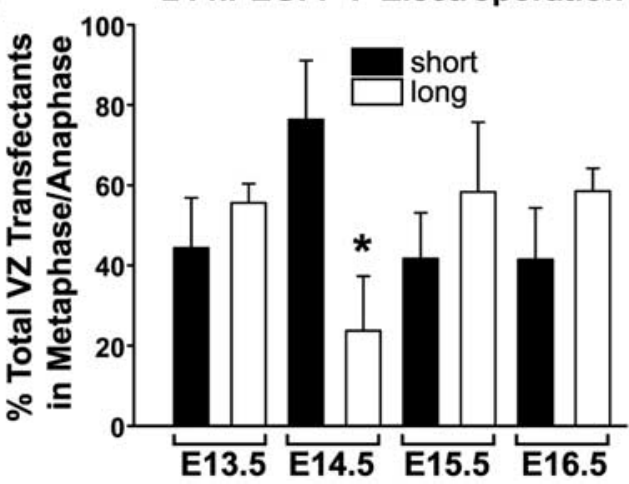

Figure 4. Quantification of VZ cell types: transfection with membrane-tagged EGFP. $\boldsymbol{A}$, Twenty-four hours after in utero cells). On each day, the ratio of long to short cells was nearly $50 \%$ and not statistically significant, although there were more SNPs found on $\mathrm{E} 14.5\left(^{*} p<0.05 ; t\right.$ test). Error bars indicate SE.

Table 2. Quantification of VZ cell types: metaphase/anaphase EGFP-F ${ }^{+}$cells

\begin{tabular}{lllll}
\hline \multicolumn{5}{l}{ Mean percentage \pm SEM } \\
\cline { 2 - 5 } & E13.5 & E14.5 & E15.5 & E16.5 \\
\hline Short & $44.4 \pm 12.45$ & $76.3 \pm 5.1$ & $41.7 \pm 11.4$ & $41.5 \pm 12.8$ \\
Long & $55.6 \pm 4.8$ & $23.7 \pm 13.6$ & $58.3 \pm 7.4$ & $58.5 \pm 5.7$ \\
\hline
\end{tabular}

tion to confirming the existence of SNPs, the EM experiments also identified RGCs, thereby validating the light microscopy experiments, which suggested that mitotic short and long cells coexist in the embryonic telencephalic VZ. Furthermore, the morphology and ultrastructural characteristics of the long cell in supplemental Figure 2 (available at www.jneurosci.org as supplemental material) further confirmed that RGCs maintain their ascending process during division, even while the basal process is still regrowing to the pial surface.

\section{Molecular classification of $\mathrm{VZ}$ progenitors}

To investigate possible molecular differences between SNPs and RGCs, we first tried to label mitotic VZ cells $24 \mathrm{~h}$ after pEGFP-F in utero electroporation using a battery of antibodies directed against neural precursor cells. Not surprisingly, all 3Dreconstructed dividing $\mathrm{VZ}$ cells were immunopositive for nestin, RC2, GLAST, and vimentin, but immunonegative for $\beta$-3- 


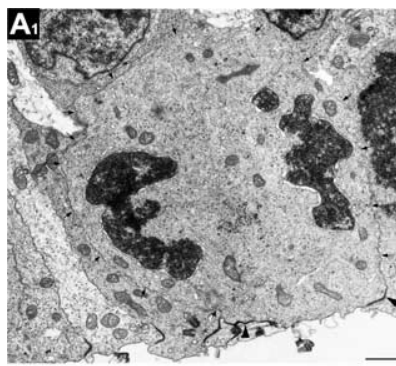

$A_{2}$
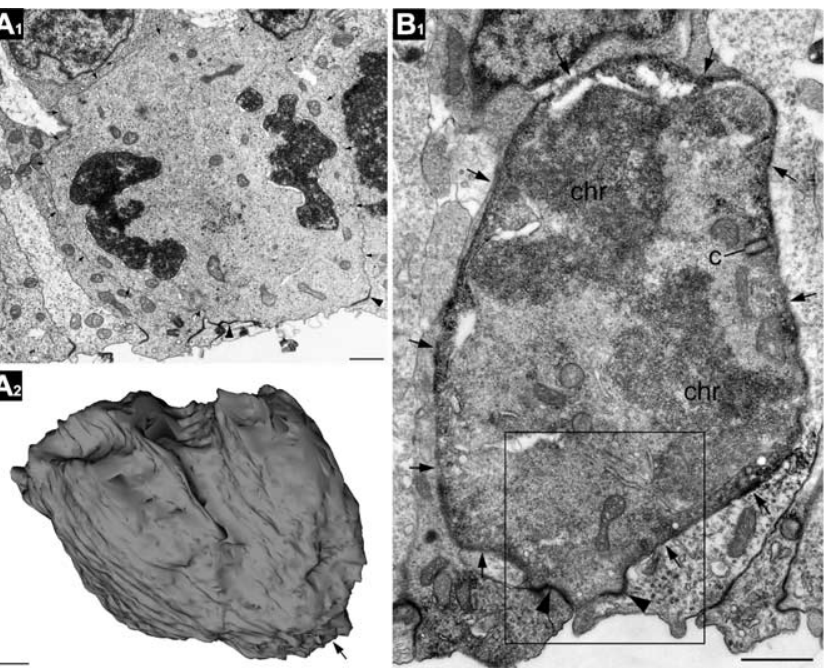

Figure 5. 3D reconstructions of SNPs by EM. $\boldsymbol{A 1}, \boldsymbol{A 2}$, This short cell in telophase was reconstructed from serial sections taken from unstained tissue from an E13.5 neocortex. The membrane of the cell is indicated with small arrows. The ventricular surface is denoted by a large arrow in the surface rendered image in $\mathbf{A 2}$. Adherens junctions are indicated by arrowheads. $\boldsymbol{B}$ 1, This E13.5 VZ cell was first labeled by in utero electroporation with EGFP-F. Subsequent anti-EGFP immunolabeling demarcated the cell border (small arrows) with electron dense immunoperoxidase-DAB reaction end-product. Two centrioles (c) located in controversial poles of the cell body (only one of which is seen in this serial section), chromosomes (chr) in cytoplasm, and fragments of forming nuclear membranes ( $\mathrm{nm}$ ) indicate that the cell is in early telophase. The framed area in $\boldsymbol{B} 1$ is enlarged in $\boldsymbol{B} 2$. $\boldsymbol{B}$ 3, 3D reconstruction from 144 contiguous serial sections demonstrates that the cell is devoid of processes. The ultrathin section in $\boldsymbol{B} \mathbf{1}$ and $\boldsymbol{B} \mathbf{2}$ is indicated by the dashed line in $\boldsymbol{B}$ 3. Scale bars: $\boldsymbol{A} \mathbf{1}-\boldsymbol{B} \mathbf{3}, 1 \boldsymbol{\mu \mathrm { m }}$.
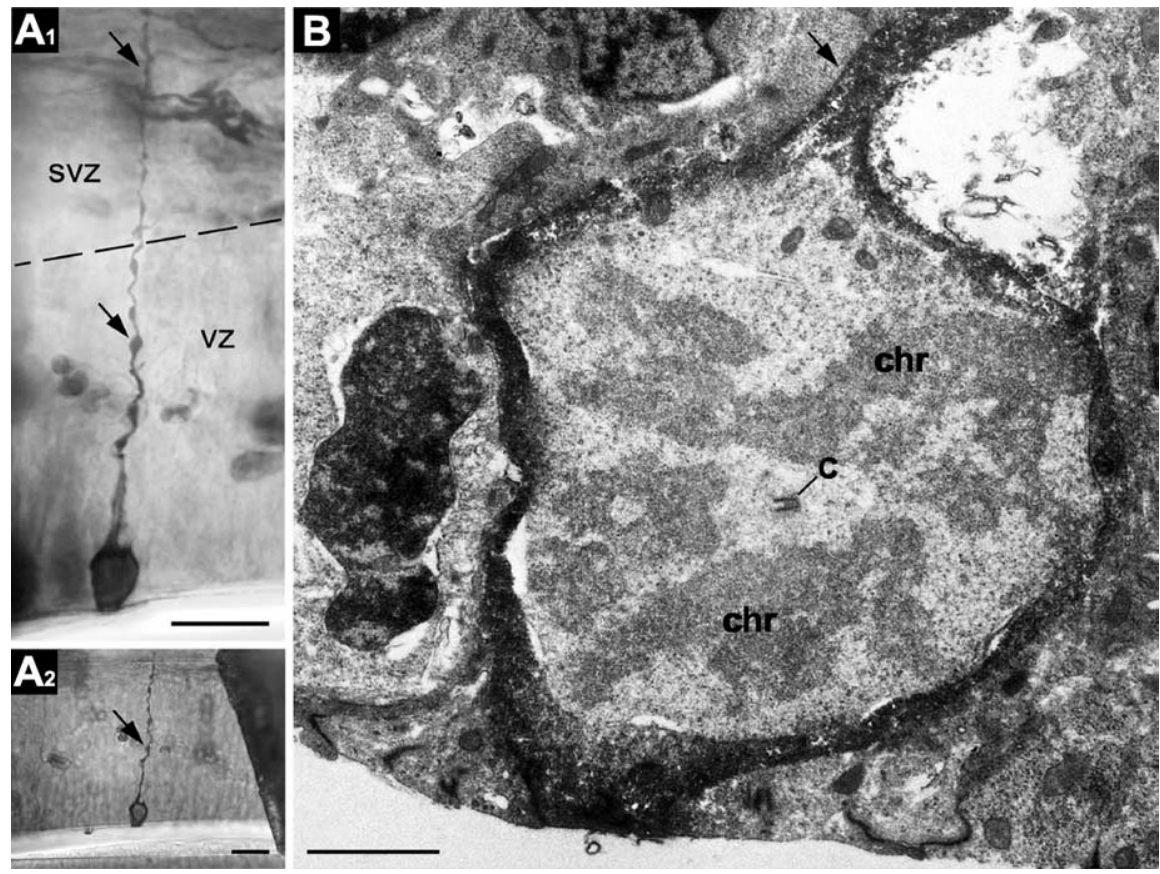

Figure 6. Light and electron micrographs of a long mitotic RGC from E14.5 dorsal telencephalic VZ. The specimen was prepared by pial placement of Dil crystals and photoconversion of the labeling into electron dense DAB precipitation. A1, Light micrograph of a long cell with the cell body situated at the ventricular surface. The process (arrows) traverses ventricular VZs and SVZs and reaches the pial surface, as suggested by Dil/DAB labeling. The border between the zones is indicated by the dashed line. $\boldsymbol{A 2}$, Specimen of the cell trimmed for ultrathin sectioning before EM investigation. The cell of interest is the only DAB-containing cell in the region. $\boldsymbol{B}$, EM image of a profile of the DAB-containing cell with initial fragment of the radial process (arrow). Chromosomes (chr) and centriole (c) in cytoplasm indicate that the cell is in metaphase. Scale bars: $A 1, A 2,20 \mu \mathrm{m} ; \boldsymbol{B}, 2 \mu \mathrm{m}$.

tubulin and microtubule-associated protein 2 (data not shown). This supports previously published reports (Gaiano et al., 2000; Hatanaka and Murakami, 2002; Noctor et al., 2002; Malatesta et al., 2003; Anthony et al., 2004) that all antigens used for specific

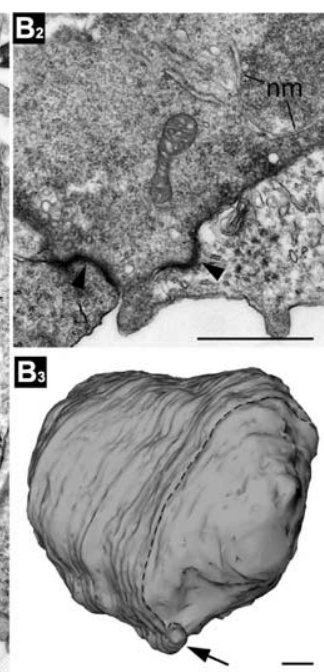

labeling of RGCs homogeneously label the neocortical VZ. However, promoter expression has been successfully used as a method to separate cell types (Wang et al., 2000; Keyoung et al., 2001). In addition, several reports have demonstrated that promoter activity can be used to label cells regardless of the translational state of the encoded protein (Mallon et al., 2002; Yuan et al., 2002). We therefore explored the possibility that differences in expression of exogenous promoters, delivered by in utero electroporation, could be correlated with each morphologically distinct VZ cell type.

To determine whether stage-and classspecific DNA promoters may distinguish SNPs from RGCs, we performed 3D confocal microscopy on VZ cells transfected in utero with constructs in which the promoters for the tubulin $\alpha-1$ gene ( $p T \alpha 1$ ), the GLAST glutamate transporter gene ( $p$ Glast), or brain lipid binding protein $(p B l b p)$ were driving GFP variants. Fortyeight hours after $\mathrm{pT} \alpha 1$ :hGFP electroporation on E13.5, GFP-labeled cells were found in the VZ and SVZ along with a massive bolus neurons migrating out of the SVZ, thorough the IZ, and into the CP (Fig. $7 A, B$ ). In addition, most $\mathrm{GFP}^{+}$neurons exhibited the classical morphology of radial migrators with thick leading processes and thin trailing processes (Fig. 7C). Because very few migrating cells were found with a leading process extending fully to the pial surface, these cells appeared to be gliophilic bipolar migrating neurons (Ramon y Cajal, 1952; Rakic, 1972) and not migrating by "somal translocation" (Morest, 1970; Sidman and Rakic, 1973; Nadarajah and Parnavelas, 2002). Most importantly, $\mathrm{GFP}^{+}$RGC fibers were largely absent in the IZ and CP of the pT $\alpha 1$ :hGFP-transfected neocortical wall, and the majority of mitotic $\mathrm{pT} \alpha 1$ $\mathrm{hGFP}^{+} \mathrm{VZ}$ cells lacked ascending processes (Fig. 7D-G; supplemental movie 5, available at www.jneurosci.org as supplemental material). In contrast, the overwhelming majority of mitotic VZ cells expressing either pGlast-EGFP or pBlbpEGFP possessed a basal ascending process (Fig. $7 F, G$ ). Thus, in the prenatal murine VZ, neurogenic SNPs preferentially express the T $\alpha 1$ promoter, previously found to be expressed by neuronal progenitor cells (Gloster et al., 1994; Sawamoto et al., 2001), whereas the Glast and Blbp promoters are specifically expressed by RGCs.

To determine the level of exclusivity of these expression patterns, we cotransfected E12 VZ cells in utero with pairs of promoter constructs in which one plasmid encoded EGFP and the other encoded DsRed2 (Fig. 7H). We found that very few VZ cells 
simultaneously expressed both the T $\alpha 1 /$ Glast or T $\alpha 1$ /Blbp promoters 24 (Fig. $7 F$ ) or $48 \mathrm{~h}$ (Fig. $7 \mathrm{G}$ ) post electroporation. In contrast, $90-95 \%$ of the cells expressing the Glast promoter also expressed the Blbp promoter. A corresponding analysis on neocortices electroporated on E14 and allowed to develop in utero for 24 or $48 \mathrm{~h}$ yielded nearly identical results to those presented in Figure $7 \mathrm{~F}-\mathrm{H}$ (data not shown). Altogether, based on their promoter activity profiles, these data demonstrate that SNPs and RGCs are molecularly different and exclusive cell types, and that the $\mathrm{pT} \alpha 1$-EGFP and pGlast-EGFP/pBlbpEGFP constructs can be used to separate these two classes of VZ cells in future studies.

\section{Short VZ cells as a separate proliferative population}

Our electroporation and EM analyses demonstrate that SNPs are present in the VZ during M-phase of the cell cycle. In addition, the T $\alpha 1$ construct studies demonstrate that this promoter, expressed in neuronal progenitors and postmitotic neurons, can be used to separately classify mitotic SNPs from mitotic RGCs. To determine whether short VZ cells are also present in other phases of the cell cycle and are therefore a separate proliferative population, we performed in utero electroporation of a variety of fluorescent constructs on E14.5, followed by cumulative BrdU labeling or Ki67 immunostaining $24 \mathrm{~h}$ after transfection (Fig. 8).

After $4 \mathrm{~h}$ of cumulative BrdU labeling just before killing (Fig. 8A), 56\% (SEM \pm 5 ) of the SNPs (bipolar in morphology and with basal contacts at the ventricular surface) were BrdU-unlabeled and therefore in $\mathrm{G}_{1}$ phase (Fig. $8 \mathrm{~B}$ ), whereas $44 \%( \pm 4)$ of the reconstructed bipolar SNPs were $\mathrm{BrdU}^{+}$(and were thus in S-phase through early $\mathrm{G}_{1}$ ) (Fig. $8 A-C$ ). In sections from brains cumulatively labeled with BrdU $6 \mathrm{~h}$ before killing (Fig. $8 D$ ), 59\% $( \pm 7)$ of the reconstructed SNPs were BrdU ${ }^{+}$, regardless of whether they were transfected with pEGFP-F (Fig. $8 E, E 1$ ) or the T $\alpha 1$ :hGFP construct (Fig. $8 \mathrm{~F}-f 2$ ). This change in the $\mathrm{BrdU}^{+}$cells from 4 to $6 \mathrm{~h}$ of BrdU labeling demonstrates that the SNP BrdU labeling index increases as expected for a continuously proliferating population and that they are not just present in M-phase. Specifically, the increase in the number of BrdU ${ }^{+}$SNPs most likely represents the combined effects of SNPs transitioning into $G_{1}$ phase, as well as the transition of (BrdU-unlabeled) SNPs into S-phase. The BrdU experiments therefore demonstrate that the SNP population progresses through the cell cycle. In addition, immunostaining for Ki67 (Fig. 8G), an antigen expressed in proliferating cells throughout the cell cycle but not in $\mathrm{G}_{0}$ phase, labeled $73 \%( \pm 7)$ of T $\alpha 1$ :hGFP cells in the VZ (Fig. $8 H-h 2$ ). Altogether, these results confirm previous reports (Gloster et al., 1994; Wang et al.,
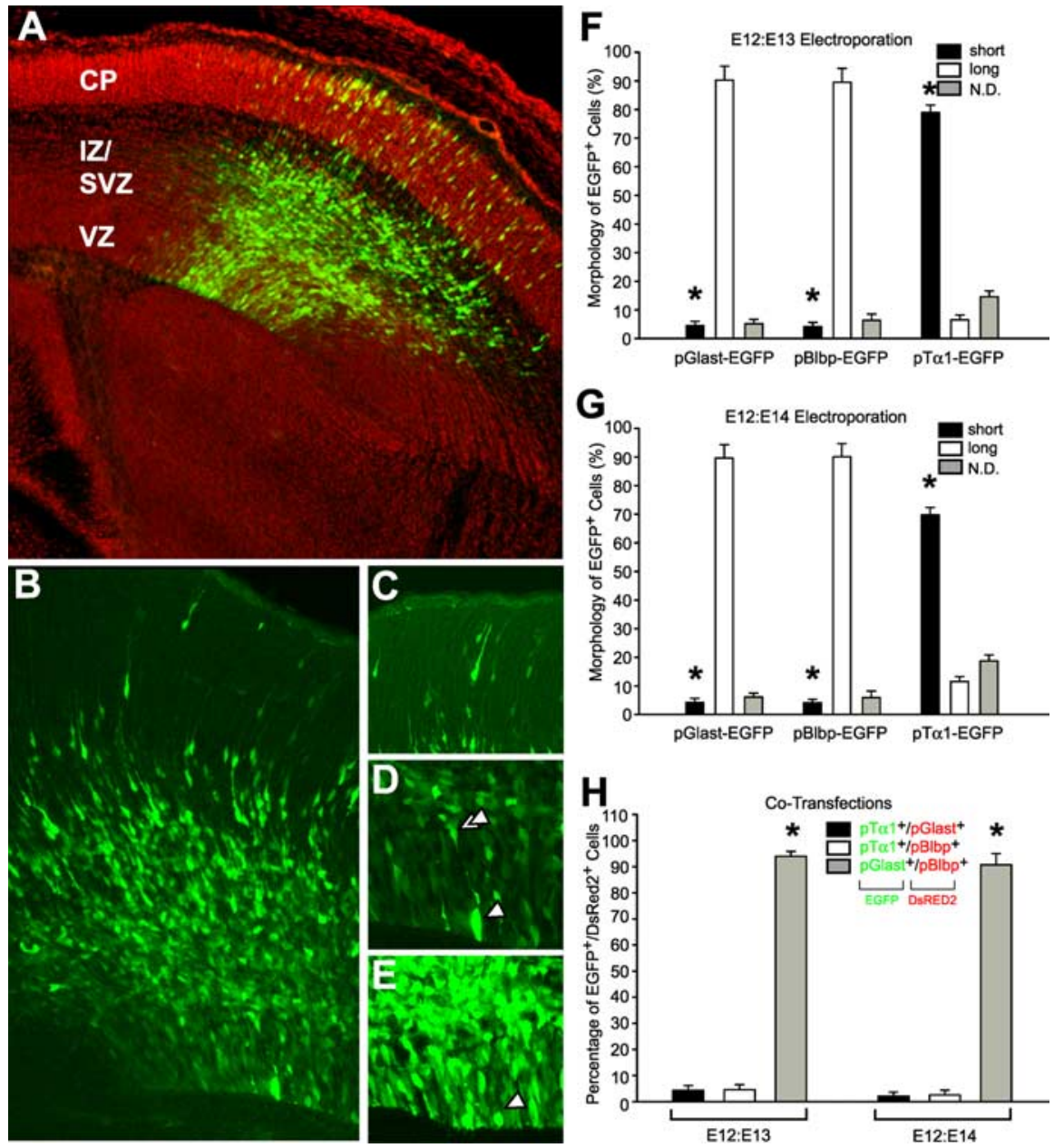

Figure 7. Electroporation of cell-specific promoters was used to differentially label short and long VZ cells. $\boldsymbol{A}-\boldsymbol{E}$, The T $\alpha 1$ promoter construct preferentially labels short VZ cells (supplemental movie 5, available at www.jneurosci.org as supplemental found in superficial portions of the neocortical wall. $C$, Most neurons migrating into the $C P$ appeared bipolar, with thin trailing

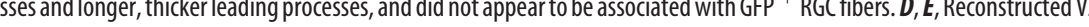
ouble arrowheads) before their entry into metaphase $(\boldsymbol{D})$, and lacked processes when dividing at the surface of the ventricle $(\boldsymbol{E})$ Dere and pBlbp-EGFP were primarily expressed by long RGCs. Conversely, short dividing cells preferentially expressed the pT $\alpha 1$-hGFP construct. The percentage of unclassifiable cells is represented as N.D. ( $>18,000$ transfected cells were scored for the experiments in $\boldsymbol{F}$ and $\boldsymbol{G}$ ). $\boldsymbol{H}$, Cotransfection of EGFP/DsRed2 plasmid pairs demonstrated that mitotic VZ cells expressing either pGlast or pBlbp did not concurrently express $\mathrm{pT} \alpha 1$, although long cells did coexpress $\mathrm{pGlast}$ and $\mathrm{pBIbp} .{ }^{*} p<0.0001$. Error bars indicate SE.

2000; Sawamoto et al., 2001) demonstrating that (1) T $\alpha 1$ :hGFP cells are an actively cycling population and not just present in M-phase, and that (2) T $\alpha 1$-expression also labels newly generated postmitotic neurons as they exit the germinal zones. Thus, the SNP cell population is an actively proliferating group of progenitors that can undergo at least one full cell cycle while in the VZ.

\section{Discussion}

Using a combination of in utero cell transfection and light and electron microscopy techniques, we demonstrate that the murine neocortical VZ contains multiple morphologically and molecularly distinct types of dividing precursor cells, which are neurogenic in nature and which coexist during all stages of prenatal neurogenesis. Thus, our findings support the classical notion that 

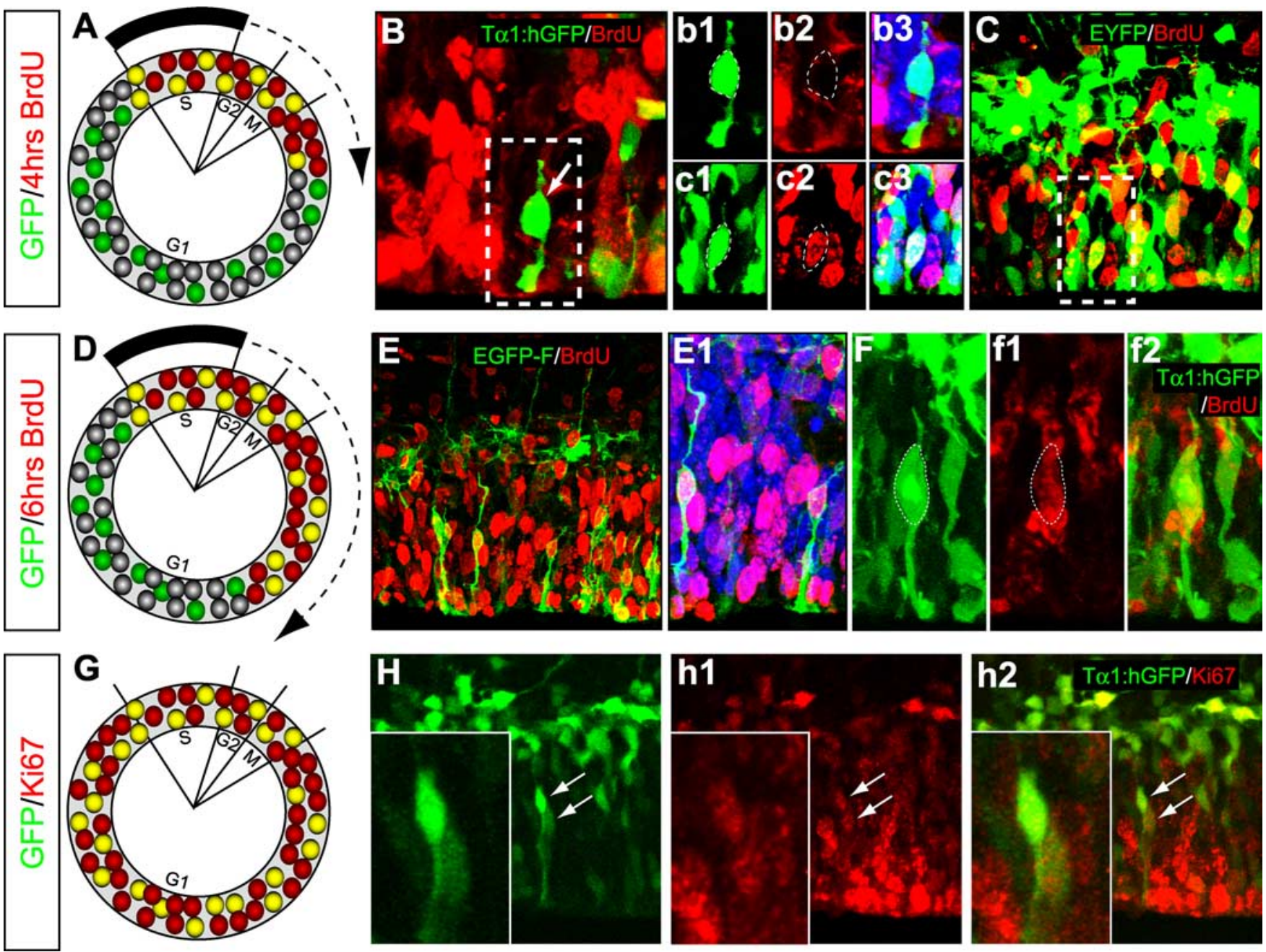

Figure 8. SNPs progress through the cell cycle. The denoted plasmid constructs were used for in utero electroporation on E14.5 followed $24 \mathrm{~h}$ later by cumulative labeling with BrdU or immunostaining for Ki67 antigen. $A-C$, Four hours of BrdU labeling identified bipolar SNPs that were labeled or unlabeled with BrdU. As depicted in $A$, BrdU ${ }^{+}$cells would be present in phases $S$-early $\mathrm{G}_{1}$ based on cell cycle parameters specified by Takahashi et al. (1995). Correspondingly, BrdU - short cells would be in mid to late $\mathrm{G}_{1}$ phase. $\boldsymbol{B}, \boldsymbol{b} \mathbf{1}-\boldsymbol{b} \mathbf{3}$, This T $\alpha 1$ : hGFP expressing cell was BrdU and therefore in $G_{1}$ phase, whereas the pEYFP-C2 expressing cell in Cand $\mathbf{c 1 - c} \mathbf{c}$ was BrdU ${ }^{+}$. D, Depiction of the cell-cycle location of BrdU ${ }^{+}$and BrdU ${ }^{-}$VZ cells after $6 \mathrm{~h}$ labeling. $\boldsymbol{E}$ - $\mathbf{f 2}$, Examples of BrdU ${ }^{+}$SNPs reconstructed after transfection with pEGFP-F and T $\alpha 1$ :hGFP. More SNPs were BrdU ${ }^{+}$after $6 \mathrm{~h}$ of cumulative BrdU exposure compared with $4 \mathrm{~h}$ BrdU exposure, suggesting that SNPs progress through the cell cycle (see text for details). $\mathbf{G}-\boldsymbol{h} \mathbf{2}$, Ki67 immunostaining also revealed that T $\alpha 1$-expressing VZ cells are arrayed throughout the cell cycle. The higher magnification insets in $\boldsymbol{H}-\mathbf{H} \mathbf{2}$ demonstrate two $\mathrm{T} \alpha 1$-expressing cells with abventricular somata that are Ki67 ${ }^{+}$

the VZ is composed of at least two cell types (His, 1904; Ramon y Cajal, 1952). These two precursors, SNPs and RGCs, are distinguished by their mitotic morphology using light and electron microscopy and by their expression of stage- and class-specific DNA promoters. These data suggest that the composition of the rodent neocortical VZ is similar to that of the primate neocortical VZ, in which RGCs and distinct progenitors are contemporaneous throughout neocortical histogenesis (Levitt et al., 1981, 1983; Saba et al., 2001; Zecevic, 2004). Our ability to discriminate multiple precursor cell types in rodent telencephalon will allow future studies aimed at identifying the molecular mechanisms underlying stem and progenitor cell expansion and/or lineage restriction and how those mechanisms cooperate during embryonic development to generate the proper size and cellular diversity in the neocortex.

Sampling techniques and/or DNA expression differences between VZ cell types are possible explanations for why we observed SNPs in this study. For example, our in utero transfection data suggest that DNA promoters may not be constitutively or equally expressed in all VZ cells. Because most retroviral studies have relied on the CMV promoter to drive GFP expression in VZ cells, this may have inadvertently oversampled the RGC population and preferentially labeled multipotent cells. When cultured at clonal density after fluorescence-activated cell sorting, we indeed found that multipotent VZ cells retain expression of CMVEGFP-F, whereas committed neuronal progenitors rapidly downregulate EGFP-F expression (D. Maric, L. Chakrabarti, J. L. Barker, and T. F. Haydar, unpublished observations). In addition, electroporation of plasmid DNA into the cell soma may sample the VZ population differently when compared with retroviral transduction, where infection is presumably influenced by the surface area, morphology, and membrane components of the ventricular foot process.

The concept that neocortical neurogenesis proceeds from a heterogeneous pool of stem cells and committed progenitors, first suggested by light microscopy, EM, and immuno-EM studies, has been supported more recently by in vitro and in vivo studies in rodents as well as in primates (Rao, 1999; McCarthy et al., 2001; Piper et al., 2001; Cai et al., 2002b; Letinic et al., 2002; Liu et al., 2002; Shen et al., 2002; Aguirre et al., 2004; Maric and Barker, 
2004; Zecevic, 2004). For example, Grove et al. (1993) used retroviral lineage analysis to identify at least six different types of restricted progenitors in the rat neocortex. However, studies in rodents using molecular genetics (Malatesta et al., 2003; Anthony et al., 2004) and time-lapse imaging of retrovirally transduced VZ cells (Noctor et al., 2001, 2002, 2004) have suggested that most, if not all, VZ cells are morphological RGCs and, furthermore, that RGCs directly generate all of the dorsally derived neocortical neurons. Species divergence has been proposed to reconcile the primate-rodent disparities in VZ constituency (Zecevic, 2004). However, the in vitro and in vivo data thus far published in rodents are only consistent if all VZ cells retain RGC morphology, even after their lineal potential diverges and/or becomes restricted. Our data, which demonstrate that short cells are also present in the rodent VZ, suggest that neither of these explanations is sufficient; rather, all of the methods demonstrate that the rodent VZ is a heterogeneous pool of long and short cells and that neocortical neurogenesis is a combined effort of both of these cell types.

The results that VZ cells differ in the expression of classspecific (radial glia versus neuronal progenitor) promoters indicate that SNPs and RGCs may represent separate stages along the continuum of cell differentiation, ranging from multipotent stem cell to postmitotic differentiated neuron. These promoter data argue against the possibility that VZ cells are simply one cell type that can assume different shapes. Importantly, there may also be heterogeneity within each long or short VZ cell group (Fishell and Kriegstein, 2003) with respect to cell cycle parameters or lineage potential. For example, in embryonic primate brain, a subclass of radial glia that form the scaffolding cease proliferation for several months during mid-gestation and serve as a migrational substrate before reactivating and dividing to produce neocortical astrocytes (Schmechel and Rakic, 1979; Rakic, 2003). These more stalwart cells contribute less to cortical expansion compared with the continuously dividing neurogenic RGCs. Although the lineage potential of neocortical precursors has been correlated with developmental age, cell cycle parameters, and signaling by exogenous factors, it is also plausible that intrinsic differences within RGC and SNP cell groups are required for the diversity of neuronal and glial cells of the neocortex, or for the maintenance and propagation of neural stem cells as they transfer into the postnatal SVZ.

This study also suggests parallels between the prenatal and postnatal neurogenesis programs. In postnatal neurogenesis, slowly dividing SVZ astrocytes (type B cells) are the stem cells which give rise to rapidly dividing transit amplifying progenitors (Doetsch et al., 1999; Doetsch, 2003). A recent study has demonstrated that RGCs generate type B stem cells in the postnatal SVZ (Merkle et al., 2004). Thus, RGCs are posited as neural stem cells in both prenatal and postnatal telencephalon. The short T $\alpha 1$ expressing VZ cells we have characterized may therefore be the prenatal correlate to the type $\mathrm{C}$ transit-amplifying progenitors found postnatally. To extend this parallel, future experiments will determine whether short and long cells differ in cell cycle kinetics in a manner similar to that found in type B and C cells.

The presence of multiple $\mathrm{VZ}$ precursors is compatible with murine fate mapping studies that have used RGC-specific promoters to assay the lineage of neocortical neurons. In particular, results from the human GFAP (hGAFP)-cAMP response element (Cre)/Rosa26R (Malatesta et al., 2003) and BLBP-Cre/R26R (Anthony et al., 2004) transgenic mice, engineered to label RGCs and their progeny, demonstrate that all dorsal neocortical excitatory neurons are derived from RGCs. In addition, in vitro data from precursor cells isolated from T $\alpha 1$-EYFP transgenic animals dem- onstrated that the T $\alpha 1$-expressing cells are restricted neuronal progenitors (Sawamoto et al., 2001). We found that short but not long VZ cells express the T $\alpha 1$-hGFP construct. Therefore, we hypothesize that SNPs are committed neuronal progenitors, which are a separate cell class but may indeed be derived from long RGCs (and thus represent an intermediate member of an hGFAP- or Blbp-promoter-expressing lineage). The existence of short cells throughout neurogenesis, the massive neurogenesis observed with the T $\alpha 1$-hGFP construct $48 \mathrm{~h}$ after transfection, and the labeling of SNPs by "RGC-specific" antibodies, are all consistent with this hypothesis.

It is generally accepted that different modes of cell division influence the expansion of precursor cells and the eventual size and complexity of the postmitotic cell population (Chenn and McConnell, 1995; Rakic, 1995; Takahashi et al., 1996; Zhong et al., 1996; Jan and Jan, 1998). For example, symmetric divisions of VZ precursor cells cause an exponential expansion in their number during early neurogenesis, whereas subsequent asymmetric cell divisions generate postmitotic neurons from VZ precursors (Rakic, 1988). Finally, at the close of neocortical neurogenesis, VZ cells again divide symmetrically to generate two postmitotic neuronal daughter cells, thereby depleting the VZ population (Takahashi et al., 1996; Haydar et al., 2003).

The switch in the general VZ population from symmetricalto-asymmetrical-to-symmetrical divisions during neurogenesis suggests either that different cell types may be responsible for each cell division mode or, conversely, that different signaling pathways operate within the same precursor cell population to modify mode of division. It has been proposed that VZ stem cells undergo the early symmetrical divisions and that RGCs perform all of the subsequent mitoses. However, RGC division has been shown in time-lapse-imaging experiments to be an inherently asymmetric enterprise with respect to both morphology and to fate; only one daughter cell inherits the RGC ascending process and the other daughter cell migrates away and becomes a neuron. To date, the symmetrical divisions that predominate during late neurogenesis have not been ascribed to a particular VZ cell type. Our results suggest the possibility that the rounded morphology of dividing SNPs may facilitate the establishment of a nonpolarized intracellular environment and promote symmetric distribution of fate-determining molecules. We speculate, therefore, that short cells may be responsible for many of the symmetrical divisions occurring throughout (Cai et al., 2002a), but especially at the end of, neocortical neurogenesis.

Together, our study reveals several classes of neocortical precursor cells that can be distinguished based on morphological and molecular criteria throughout neurogenesis. This finding is important both conceptually and practically as the prospect of using neural stem cells in potential replacement therapies increases. This ability to discriminate VZ cell types will aid in future experiments to determine the precise lineal relationship between RGCs and SNPs, as well as the molecular controls for stem cell and progenitor cell specification during vertebrate neocortical expansion.

\section{References}

Aguirre A, Gallo V (2004) Postnatal neurogenesis and gliogenesis in the olfactory bulb from NG2-expressing progenitors of the subventricular zone. J Neurosci 24:10530-10541.

Aguirre AA, Chittajallu R, Belachew S, Gallo V (2004) NG2-expressing cells in the subventricular zone are type C-like cells and contribute to interneuron generation in the postnatal hippocampus. J Cell Biol 165:575-589.

Akamatsu W, Okano HJ, Osumi N, Inoue T, Nakamura S, Sakakibara S, 
Miura M, Matsuo N, Darnell RB, Okano H (1999) Mammalian ELAVlike neuronal RNA-binding proteins $\mathrm{HuB}$ and $\mathrm{HuC}$ promote neuronal development in both the central and the peripheral nervous systems. Proc Natl Acad Sci USA 96:9885-9890.

Angevine JB, Sidman RL (1961) Autoradiographic study of cell migration during histogenesis of the cerebral cortex in the mouse. Nature 192:766-768.

Anthony TE, Klein C, Fishell G, Heintz N (2004) Radial glia serve as neuronal progenitors in all regions of the central nervous system. Neuron 41:881-890.

Cai L, Hayes NL, Takahashi T, Caviness Jr VS, Nowakowski RS (2002a) Size distribution of retrovirally marked lineages matches prediction from population measurements of cell cycle behavior. J Neurosci Res 69:731-744.

Cai J, Wu Y, Mirua T, Pierce JL, Lucero MT, Albertine KH, Spangrude GJ, Rao MS (2002b) Properties of a fetal multipotent neural stem cell (NEP cell). Dev Biol 251:221-240.

Caviness Jr VS (1982) Neocortical histogenesis in normal and reeler mice: a developmental study based upon $\left[{ }^{3} \mathrm{H}\right]$ thymidine autoradiography. Brain Res 256:293-302.

Caviness Jr VS, Sidman RL (1973) Time of origin or corresponding cell classes in the cerebral cortex of normal and reeler mutant mice: an autoradiographic analysis. J Comp Neurol 148:141-151.

Chenn A, McConnell SK (1995) Cleavage orientation and the asymmetric inheritance of Notch1 immunoreactivity in mammalian neurogenesis. Cell 82:631-641.

deAzevedo LC, Fallet C, Moura-Neto V, Daumas-Duport C, Hedin-Pereira C, Lent R (2003) Cortical radial glial cells in human fetuses: depthcorrelated transformation into astrocytes. J Neurobiol 55:288 -298.

Doetsch F (2003) The glial identity of neural stem cells. Nat Neurosci 6:1127-1134

Doetsch F, Caille I, Lim DA, Garcia-Verdugo JM, Alvarez-Buylla A (1999) Subventricular zone astrocytes are neural stem cells in the adult mammalian brain. Cell 97:703-716.

Fiala JC, Harris KM (2001) Cylindrical diameters method for calibrating section thickness in serial electron microscopy. J Microsc 202:468-472.

Fishell G, Kriegstein AR (2003) Neurons from radial glia: the consequences of asymmetric inheritance. Curr Opin Neurobiol 13:34-41.

Fukuchi-Shimogori T, Grove EA (2001) Neocortex patterning by the secreted signaling molecule FGF8. Science 294:1071-1074.

Gadisseux JF, Evrard P, Misson JP, Caviness VS (1989) Dynamic structure of the radial glial fiber system of the developing murine cerebral wall. An immunocytochemical analysis. Brain Res Dev Brain Res 50:55-67.

Gaiano N, Nye JS, Fishell G (2000) Radial glial identity is promoted by Notch1 signaling in the murine forebrain. Neuron 26:395-404.

Gloster A, Wu W, Speelman A, Weiss S, Causing C, Pozniak C, Reynolds B, Chang E, Toma JG, Miller FD (1994) The T $\alpha 1 \alpha$-tubulin promoter specifies gene expression as a function of neuronal growth and regeneration in transgenic mice. J Neurosci 14:7319-7330.

Grove EA, Williams BP, Li DQ, Hajihosseini M, Friedrich A, Price J (1993) Multiple restricted lineages in the embryonic rat cerebral cortex. Development 117:553-561.

Hatanaka Y, Murakami F (2002) In vitro analysis of the origin, migratory behavior, and maturation of cortical pyramidal cells. J Comp Neurol 454:1-14.

Hatten ME (1993) The role of migration in central nervous system neuronal development. Curr Opin Neurobiol 3:38-44.

Haydar TF, Bambrick LL, Krueger BK, Rakic P (1999) Organotypic slice cultures for analysis of proliferation, cell death, and migration in the embryonic neocortex. Brain Res Brain Res Protoc 4:425-437.

Haydar TF, Wang F, Schwartz ML, Rakic P (2000) Differential modulation of proliferation in the neocortical ventricular and subventricular zones. J Neurosci 20:5764-5774.

Haydar TF, Ang Jr E, Rakic P (2003) Mitotic spindle rotation and mode of cell division in the developing telencephalon. Proc Natl Acad Sci USA 100:2890-2895.

Hinds JW, Ruffett TL (1971) Cell proliferation in the neural tube: an electron microscopic and golgi analysis in the mouse cerebral vesicle. Z Zellforsch Mikrosk Anat 115:226-264.

His W (1904) Die entwicklung des menschlichen gehirns wahrend der ersten monate. Leipzig: Hirzel.

Hunter KE, Hatten ME (1995) Radial glial cell transformation to astrocytes is bidirectional: regulation by a diffusible factor in embryonic forebrain. Proc Natl Acad Sci USA 92:2061-2065.

Jan YN, Jan LY (1998) Asymmetric cell division. Nature 392:775-778.

Kamei Y, Inagaki N, Nishizawa M, Tsutsumi O, Taketani Y, Inagaki M (1998) Visualization of mitotic radial glial lineage cells in the developing rat brain by Cdc2 kinase-phosphorylated vimentin. Glia 23:191-199.

Keyoung HM, Roy NS, Benraiss A, Louissaint Jr A, Suzuki A, Hashimoto M, Rashbaum WK, Okano H, Goldman SA (2001) High-yield selection and extraction of two promoter-defined phenotypes of neural stem cells from the fetal human brain. Nat Biotechnol 19:843-850.

Letinic K, Zoncu R, Rakic P (2002) Origin of GABAergic neurons in the human neocortex. Nature 417:645-649.

Levitt P, Cooper ML, Rakic P (1981) Coexistence of neuronal and glial precursor cells in the cerebral ventricular zone of the fetal monkey: an ultrastructural immunoperoxidase analysis. J Neurosci 1:27-39.

Levitt P, Cooper ML, Rakic P (1983) Early divergence and changing proportions of neuronal and glial precursor cells in the primate cerebral ventricular zone. Dev Biol 96:472-484.

Liu Y, Wu Y, Lee JC, Xue H, Pevny LH, Kaprielian Z, Rao MS (2002) Oligodendrocyte and astrocyte development in rodents: an in situ and immunohistological analysis during embryonic development. Glia 40:25-43.

Malatesta P, Hack MA, Hartfuss E, Kettenmann H, Klinkert W, Kirchhoff F, Gotz M (2003) Neuronal or glial progeny: regional differences in radial glia fate. Neuron 37:751-764.

Mallon BS, Shick HE, Kidd GJ, Macklin WB (2002) Proteolipid promoter activity distinguishes two populations of NG2-positive cells throughout neonatal cortical development. J Neurosci 22:876-885.

Maric D, Barker JL (2004) Neural stem cells redefined: a FACS perspective. Mol Neurobiol 30:49-76.

Maric D, Maric I, Chang YH, Barker JL (2000) Stereotypical physiological properties emerge during early neuronal and glial lineage development in the embryonic rat neocortex. Cereb Cortex 10:729-747.

Maric D, Maric I, Chang YH, Barker JL (2003) Prospective cell sorting of embryonic rat neural stem cells and neuronal and glial progenitors reveals selective effects of basic fibroblast growth factor and epidermal growth factor on self-renewal and differentiation. J Neurosci 23:240-251.

McCarthy M, Turnbull DH, Walsh CA, Fishell G (2001) Telencephalic neural progenitors appear to be restricted to regional and glial fates before the onset of neurogenesis. J Neurosci 21:6772-6781.

McConnell SK (1988) Development and decision-making in the mammalian cerebral cortex. Brain Res 472:1-23.

Merkle FT, Tramontin AD, Garcia-Verdugo JM, Alvarez-Buylla A (2004) Radial glia give rise to adult neural stem cells in the subventricular zone. Proc Natl Acad Sci USA 101:17528-17532.

Misson JP, Edwards MA, Yamamoto M, Caviness Jr VS (1988) Mitotic cycling of radial glial cells of the fetal murine cerebral wall: a combined autoradiographic and immunohistochemical study. Brain Res 466:183-190.

Miyasaka N, Arimatsu Y, Takiguchihayashi K (1999) Foreign gene expression in an organotypic culture of cortical anlage after in vivo electroporation. NeuroReport 10:2319-2323.

Miyata T, Kawaguchi A, Okano H, Ogawa M (2001) Asymmetric inheritance of radial glial fibers by cortical neurons. Neuron 31:727-741.

Miyata T, Kawaguchi A, Saito K, Kuramochi H, Ogawa M (2002) Visualization of cell cycling by an improvement in slice culture methods. J Neurosci Res 69:861-868.

Morest DK (1970) A study of neurogenesis in the forebrain of opossum pouch young. Z Anat Entwicklungsgesch 130:265-305.

Nadarajah B, Parnavelas JG (2002) Modes of neuronal migration in the developing cerebral cortex. Nat Rev Neurosci 3:423-432.

Nadarajah B, Alifragis P, Wong RO, Parnavelas JG (2003) Neuronal migration in the developing cerebral cortex: observations based on real-time imaging. Cereb Cortex 13:607-611.

Noctor SC, Flint AC, Weissman TA, Dammerman RS, Kriegstein AR (2001) Neurons derived from radial glial cells establish radial units in neocortex. Nature 409:714-720.

Noctor SC, Flint AC, Weissman TA, Wong WS, Clinton BK, Kriegstein AR (2002) Dividing precursor cells of the embryonic cortical ventricular zone have morphological and molecular characteristics of radial glia. J Neurosci 22:3161-3173.

Noctor SC, Martinez-Cerdeno V, Ivic L, Kriegstein AR (2004) Cortical neu- 
rons arise in symmetric and asymmetric division zones and migrate through specific phases. Nat Neurosci 7:136-144.

Nowakowski RS, Rakic P (1981) The site of origin and route and rate of migration of neurons to the hippocampal region of the rhesus monkey. J Comp Neurol 196:129-154.

Ostenfeld T, Svendsen CN (2004) Requirement for neurogenesis to proceed through the division of neuronal progenitors following differentiation of epidermal growth factor and fibroblast growth factor-2-responsive human neural stem cells. Stem Cells 22:798-811.

Piper DR, Mujtaba T, Keyoung H, Roy NS, Goldman SA, Rao MS, Lucero MT (2001) Identification and characterization of neuronal precursors and their progeny from human fetal tissue. J Neurosci Res 66:356-368.

Pixley SK, de Vellis J (1984) Transition between immature radial glia and mature astrocytes studied with a monoclonal antibody to vimentin. Brain Res 317:201-209.

Rakic P (1971) Guidance of neurons migrating to the fetal monkey neocortex. Brain Res 33:471-476.

Rakic P (1972) Mode of cell migration to the superficial layers of fetal monkey neocortex. J Comp Neurol 145:61-83.

Rakic P (1974) Neurons in rhesus monkey visual cortex: systematic relation between time of origin and eventual disposition. Science 183:425-427.

Rakic P (1988) Specification of cerebral cortical areas. Science 241:170-176.

Rakic P (1995) A small step for the cell, a giant leap for mankind: a hypothesis of neocortical expansion during evolution. Trends Neurosci 18:383-388.

Rakic P (2003) Developmental and evolutionary adaptations of cortical radial glia. Cereb Cortex 13:541-549.

Ramon y Cajal S (1952) Histologie du systeme nerveux de l'homme et des vertebres. Reprint (Consejo Superior de Investigaciones Cientificas Edition). Paris: A. Maloine.

Rao MS (1999) Multipotent and restricted precursors in the central nervous system. Anat Rec 257:137-148.

Rowley III JC, Moran DT (1975) A simple procedure for mounting wrinklefree sections on formvar-coated slot grids. Ultramicroscopy 1:151-155.

Roy NS, Wang S, Jiang L, Kang J, Benraiss A, Harrison-Restelli C, Fraser RA, Couldwell WT, Kawaguchi A, Okano H, Nedergaard M, Goldman SA (2000) In vitro neurogenesis by progenitor cells isolated from the adult human hippocampus. Nat Med 6:271-277.

Saba S, Barrington W, Ganz LI (2001) Wide and narrow complex tachycardias: what is the mechanism? Pacing Clin Electrophysiol 24:1810-1811.

Saito T, Nakatsuji N (2001) Efficient gene transfer into the embryonic mouse brain using in vivo electroporation. Dev Biol 240:237-246.

Sauer FC (1935) The cellular structure of the neural tube. J Comp Neurol:13-23.

Sauer ME, Walker BE (1959) Radioautographic study of interkinetic nuclear migration in the neural tube. Proc Soc Exp Biol Med 101:557-560.

Sawamoto K, Yamamoto A, Kawaguchi A, Yamaguchi M, Mori K, Goldman SA, Okano H (2001) Direct isolation of committed neuronal progenitor cells from transgenic mice coexpressing spectrally distinct fluorescent proteins regulated by stage-specific neural promoters. J Neurosci Res 65:220-227.

Schmechel DE, Rakic P (1979) Arrested proliferation of radial glial cells during midgestation in rhesus monkey. Nature 277:303-305.

Shen Q, Zhong W, Jan YN, Temple S (2002) Asymmetric Numb distribution is critical for asymmetric cell division of mouse cerebral cortical stem cells and neuroblasts. Development 129:4843-4853.

Shoukimas GM, Hinds JW (1978) The development of the cerebral cortex in the embryonic mouse: an electron microscopic serial section analysis. J Comp Neurol 179:795-830.

Sidman RL, Rakic P (1973) Neuronal migration, with special reference to developing human brain: a review. Brain Res 62:1-35.

Stensaas LJ, Stensaas SS (1968) An electron microscope study of cells in the matrix and intermediate laminae of the cerebral hemisphere of the $45 \mathrm{~mm}$ rabbit embryo. Z Zellforsch Mikrosk Anat 91:341-365.

Tabata H, Nakajima K (2001) Efficient in utero gene transfer system to the developing mouse brain using electroporation: visualization of neuronal migration in the developing cortex. Neuroscience 103:865-872.

Tabata H, Nakajima K (2003) Multipolar migration: the third mode of radial neuronal migration in the developing cerebral cortex. J Neurosci 23:9996-10001.

Takahashi T, Misson JP, Caviness Jr VS (1990) Glial process elongation and branching in the developing murine neocortex: a qualitative and quantitative immunohistochemical analysis. J Comp Neurol 302:15-28.

Takahashi T, Nowakowski RS, Caviness Jr VS (1995) The cell cycle of the pseudostratified ventricular epithelium of the embryonic murine cerebral wall. J Neurosci 15:6046-6057.

Takahashi T, Nowakowski RS, Caviness Jr VS (1996) The leaving or Q fraction of the murine cerebral proliferative epithelium: a general model of neocortical neuronogenesis. J Neurosci 16:6183-6196.

Wang S, Roy NS, Benraiss A, Goldman SA (2000) Promoter-based isolation and fluorescence-activated sorting of mitotic neuronal progenitor cells from the adult mammalian ependymal/subependymal zone. Dev Neurosci 22:167-176.

Weissman T, Noctor SC, Clinton BK, Honig LS, Kriegstein AR (2003) Neurogenic radial glial cells in reptile, rodent and human: from mitosis to migration. Cereb Cortex 13:550-559.

Yuan X, Chittajallu R, Belachew S, Anderson S, McBain CJ, Gallo V (2002) Expression of the green fluorescent protein in the oligodendrocyte lineage: a transgenic mouse for developmental and physiological studies. J Neurosci Res 70:529-545.

Zecevic N (2004) Specific characteristic of radial glia in the human fetal telencephalon. Glia 48:27-35.

Zhong W, Feder JN, Jiang MM, Jan LY, Jan YN (1996) Asymmetric localization of a mammalian numb homolog during mouse cortical neurogenesis. Neuron 17:43-53. 